\title{
Synthesis of Lapachol Analogues through Suzuki-Miyaura Cross-Coupling. Antitumoral Evaluation.
}

\author{
Gomes, S. L. S. ${ }^{1}$; Costa, A. M. ${ }^{2}$; Militão, G. C. G. ${ }^{2}$; Costa, P. R. R. ${ }^{1}$; da Silva, A. J. M. ${ }^{* 3}$ \\ ${ }^{1}$ Laboratório de Química Bioorgânica, Núcleo de Pesquisa de Produtos Naturais, Universidade Federal do \\ Rio de Janeiro, Brazil;; ${ }^{2}$ Departamento de Fisiologia e Farmacologia, Universidade Federal de Pernambuco, \\ ${ }^{3}$ Núcleo de Pesquisa de Produtos Naturais, Universidade Federal do Rio de Janeiro,Brazil.
}

\section{*e-mail: alcides@nppn.ufri.br and saralsg@hotmail.com}

Keywords: Lapachol, palladium, Suzuki-Miyaura

\section{INTRODUCTION}

Lapachol (Figure 1) is a naphtoquinone extracted from the bark of Pau d'Arco. This compound presents antineoplasic activity that is associated to the DNA repair inhibition and also acts as an oxidation and phosphorylation inhibitor in the mitochondria. It is believed that the presence of the prenyl group is important to the observed activity. Recently, the molluscicidal, antimalarial, antitrypanosomal and antiviral activities of lapachol and analogues have been reported. ${ }^{1}$<smiles>CC(C)=CCC1C(=O)c2ccccc2C(=O)C1O</smiles>

Figure 1. Lapachol

\section{RESULTS AND DISCUSSION}

Our purpose in this work is to synthesize new lapachol analogues type (5), in which the olefin moiety at the side chain in $\mathbf{1}$ is replaced for aromatic groups, employing the Suzuki-Miyaura crosscoupling reactions between (3) and (4) and analyze their antitumoral profiles.

Lawsone (2), used as starting material, was transformed into 3 -iodine-lawsone (3) in $80 \%$ yield, using the morpholine-iodine complex (Scheme 1). ${ }^{2}$

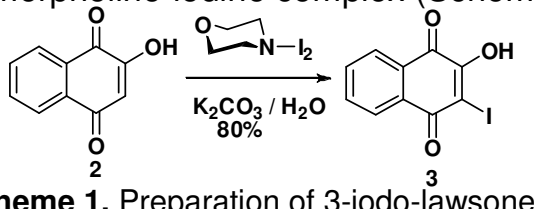

Scheme 1. Preparation of 3-iodo-lawsone Then, the cross-coupling reactions were conducted under different reactional conditions ${ }^{3 a, b, c}$ in order to find the most favorable to our system (Scheme 2), and then optimize it (Table 1).

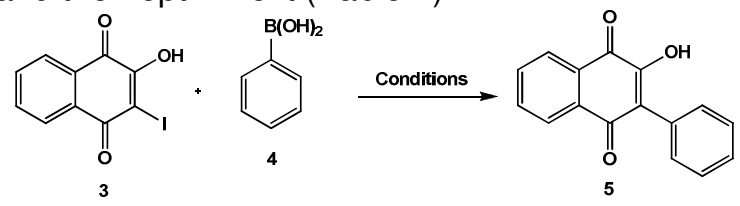

Conditions: $\mathrm{A}=\mathrm{Pd}(\mathrm{PPH})_{3}, \mathrm{Na}_{2} \mathrm{CO}_{3}, \mathrm{DME} / \mathrm{EtOH}, 85^{\circ} \mathrm{C}(60 \%)$; $\mathrm{B}=\mathrm{Pd}\left(\mathrm{PPH}_{3}\right)_{4}, \mathrm{~K}_{3} \mathrm{PO}_{4}, \mathrm{DMF}, 110^{\circ} \mathrm{C}(\%)$ not determinated; $\mathrm{C}=\mathrm{Pd} / \mathrm{C}, \mathrm{K}_{2} \mathrm{CO}_{3}$, Dioxane $/ \mathrm{H}_{2} \mathrm{O}, 95^{\circ} \mathrm{C}(83 \%)$

Scheme 2. Suzuki-Miyaura reaction between 3 and 4.
Table 1. Yields for reactions of Scheme 1

\begin{tabular}{|c|c|c|c|c|}
\hline Entry & $(\mathbf{3})$ & $(\mathbf{4})$ & $\mathrm{Pd} / \mathrm{C}$ & $(\mathbf{5})$ Yield\% \\
\hline 1 & $1 \mathrm{eq}$ & $2 \mathrm{eq}$ & $10 \mathrm{~mol} \%$ & $89 \%$ \\
\hline 2 & $1 \mathrm{eq}$ & $2 \mathrm{eq}$ & $5 \mathrm{~mol} \%$ & $99 \%$ \\
\hline 3 & $1 \mathrm{eq}$ & $2 \mathrm{eq}$ & $1 \mathrm{~mol} \%$ & $95 \%$ \\
\hline 4 & $1 \mathrm{eq}$ & $1.4 \mathrm{eq}$ & $5 \mathrm{~mol} \%$ & $85 \%$ \\
\hline
\end{tabular}

Other aryl-boronic acids were tested under the optimized conditions $\mathrm{C}$, which gave better results providing the expected products in good yields. Afterward, the hydroxyl group of the lapachol analogues was protected in the form of OAc or $\mathrm{OCONEt}_{2}{ }^{4}$ in order to enhance their lipophilic character, and their antitumoral profiles were also analyzed, rendering promising results.

\section{CONCLUSION}

The cross-coupling reaction conducted under conditions $\mathrm{C}$, presented better results and the optimization of the reaction allowed excellent yields of the synthesis of lapachol analogues, using few quantity of the catalyst.

\section{ACKNOWLEDGEMENTS}

UFRJ, CAPES, CNPq, PIBIC, FINEP, FAPERJ, UFP and the NPPN Analytical Center.

\section{REFERENCES}

Hussain, H.; Krohn, K.; Ahmad, V. U.; Miana, G. A.; Green, I. R.; ARKIVOC 2007 (ii), 145.

${ }^{2}$ L. C. R. M.; Canavez, R. C. P.; Gomes, S. L. S.; da Silva, A. J. M.; Costa, P. R. R.; J. Braz. Chem. Soc. 2009, 1916.

3a Suzuki, A.; J. Organomet Chem. 2002, 653, 83. ${ }^{3 b}$ Watanabe, T. Miyaura, N.; Suzuki, A.; Synlett 1992, 207. , ${ }^{3 c}$ Pousse, G.; Devineau, A.; Dalla, V.; Humphreys, L.; Lasne, M. C.; Rouden, J.; Blanchet, J.; Tetrahedron 2009, 10617.

${ }^{4}$ Greene, T. W.; Wuts, P. G. M.; Protective Groups in Organic Synthesis $4^{\text {th }}$ edition, John Wiley \& Sons, INC, 2007. 